\title{
The Interpretations, Problems and Possibilities of Missionary Sources in the History of Christianity in Africa
}

\author{
Emma Wild-Wood
}

Studies in World Christianity have often analysed a variety of religious expression by attending to local responses under-represented in global church structures. Many historians of World Christianity emphasise the plurality within Christianity by seeking indigenous perspectives on the processes of religious change, Christian development and transnational influence. Frequently, much historical evidence for the activities and reception of early Christian converts, church workers and religious movements is found in the vast corpus of documentation produced and preserved by western missionary societies in Europe, North America and the Antipodes. This literature has been considered flawed evidence, focussed upon the concerns of missionaries, their societies and supporters, and therefore unrepresentative of the social, political and economic dynamics of communities that missionaries were working amongst and dismissive of their cultural norms. From around 1990, however, approaches to World Christianity studies have been influenced by a renewed use of missionary archives by historians and anthropologists. This chapter starts by reviewing the variety of theoretical perspectives produced through the use of mission sources to understand historical processes of social and religious change. The second section of the chapter provides a detailed study of an event described in a missionary source in order to enquire in depth into the problems and possibilities of the sources. The final section of the chapter furthers this enquiry by examining the nature of missionary sources. This chapter illustrates its discussion of the problems and possibilities of missionary literature largely with reference to nineteenth and twentieth century European and Protestant sources in sub-Saharan Africa. Nevertheless, it shows that missionary sources are particularly informative about the participation of indigenous Christians in a global movement which comprised common threads as well as distinct, local practices. 


\section{Interpretation}

The rise in the use of missionary archives has been influenced by a transnational turn in history and social science and an acknowledgement of a strong link between religious activity and transnationalism (Harries and Maxwell 2012; Manktelow 2013; Porter 2004; Sivasundaram 2005). Christianity has spread across the globe since its inception and the missionary movements of the early modern and modern periods took advantage of the increased speed of travel, communication and trade of their eras. Christians in the Global South are, therefore, part of a quintessentially globalized or transnational phenomenon. Identifying their role-or lack of it-in shaping the early reception of Christianity has been of interest to historians and anthropologists. Missionary archives have been used to support two broad, and at times overlapping, assessments regarding cultural change which are examined below. The first, often influenced by postcolonial theories, holds that Christian mission is a form of cultural assault often associated with colonial practice or assumptions and, furthermore, that mission activities marginalise and alienate indigenous populations and increase the inequitable distribution of resources and power. The second view, more common in World Christianity studies, considers that mission is a form of cultural exchange. In this view, conversion not only changes the convert but also the missionary. The result of this change is a new form of Christianity that is embedded in a new situation. What follows is a review of this literature to demonstrate how the interpretation of missionary sources-often combined with other evidence and theorisation-has developed a number of views on Christianity worldwide.

Missionary sources were initially avoided by those who understood missionary activity as an iconoclastic assault on indigenous cultures. V-Y Mudimbe (1988) claimed that the missionary was 'an agent of a political empire, a representative of a civilisation, and an envoy of God,' intent upon 'the conversion of African minds and space.' Africans converted not through choice but as a technique for survival. Missionaries' commitment to learning language and culture - their 'softening influence' (Tiberondwa 1998: vii-viii)—only made their imposition more effective. An engagement with missionary sources did not change this view. The seminal work of anthropologists Jean and John Comaroff prompted a renewed attention to missionary activity as a site of enquiry into social and cultural change and their assumptions of missionary influence were similar to those of Mudimbe. Of Revelation and Revolution (1991) examined the response of the Tswana to the London Missionary Society (LMS). Drawing on Foucault's comprehension of the normalisation of social power, 
and Gramscian notions of hegemony, it presented the colonial and missionary encounters with Africans as being intrinsically bound together, resulting in a colonisation of the very consciousness of Africans. The Comaroffs' focus on encounter collapsed the conceptual boundaries between monolithic interpretations of 'African' and 'Imperial' and examined the cultural changes - through foreign influence in their language and thought forms-wrought among Africans as a result of colonialism. However, the lack of agency accorded to Africans in the Comaroff study, the limitations of describing the encounter as single rather than seeing it from a number of angles, and the failure to engage with African texts and oral narratives have all been widely criticised (Peel 1995; Peterson 2011). Nancy Rose Hunt, utilising post-colonial studies on subalterns, is better able to discern African agency whilst remaining attentive to the asymmetries of power that are maintained through social relations. In A Colonial Lexicon (1999) she uses Baptist Missionary Society archives to provide historical evidence for the dismantling of African orders and the construction of syncretistic colonial orders. She studies those Africans who mediated knowledge, who mimicked or mocked missionary and colonial practices in order to make meaning, who invested in linguistic and cultural change. Ultimately, for Hunt, however, transnational forces are always negatively intrusive: technologies introduced in the colonial era were insuperably infused with imperial meaning, cultural change was coercive and arose from mutual misunderstanding and distrust. The foreign assault on indigenous cultures, as presented by Hunt and the Comaroffs, has raised issues of power and alterity, through analysis of unequal relations, coercion, uncomfortable encounters, misconceptions, cultural difference and through interpreting the silences as awkward reminders of imbalances in missionary sources.

Views of Christian mission as a form of cultural exchange have critiqued hegemonic constructions of Empire. Until recently, however, this scholarship in World Christianity studies was ambivalent about missionary sources. It considered that exchange was most successful when indigenous populations created a distinct Christian church, independent of missionary control or western practice. It researched the rise of locally initiated churches and autonomous Christian movements using oral history methods where possible in order to seek 'authentic' African voices (Kollman 2010: 19). The approach has been critiqued as one which 'dismissed metropolitan influences as of no more than minimal significance.' (Porter 2004: 3-4). Yet the concentration on locality emerged from a concern that metropolitan sources and interpretations would unduly influence, even corrupt, the indigenous motives and processes that can be obscured in the colonial record. 
More recently, this stream of literature has utilised missionary sources and has turned attention towards mission initiated Christianity. Anthropologist, Birgit Meyer, for example, deliberately examined both mission and independent churches as examples of the local appropriation of Christianity. In Translating the Devil (1999) she used the archives of the Norddeutsche Missionsgesellschaft to analyse ideas about the personification of evil as a product of the encounter between German missionaries and the Ewe. By taking this approach she critiqued the assumption of total colonial suppression of Africans, preferring to analyse the ways in which internal motivations for change prompt negotiation and challenge of inequalities within missionary settings. JDY Peel in Religious Encounter and the Making of the Yoruba (2000) demonstrated the value of missionary resources for examining cultural encounter by mining the CMS archives on the Yoruba. Peel examines the correspondence of cMs personnel from the Krio population of Sierra Leone, who often had Yoruba heritage and who returned to the Yoruba lands to work as Christian missionaries (Peel 1996). Using these missionary sources Peel demonstrates the role of missionary work in the contested introduction of new ideas and practices for the Yoruba that promoted wider units of belonging and which aided the creation of ethno-national entities. The Krio and Yoruba personnel were fully involved in cultural change which they considered to be advantageous and desirable. Furthermore, Peel showed how missionary work encouraged a trans-temporal belonging in which converts read themselves into the biblical stories of the Ancient Middle East, often producing interpretations which challenged those of Europeans.

The mission station as site of cultural exchange has drawn the attention of a number of historians interested in the transnational flows of ideas, values and artefacts and emerging Christianised cultural forms. They are influenced by changes in World History which have complicated the narrative of imperial imposition by a reading of the imperial metropole and the colony as a single analytic field in which there is a mutual shaping and reordering (Cooper and Stoler 1997: 1; Bayly 2004: 470). Some examine the "construction of subjectivities in the colonial setting" through complex interactions which allows a "unique site of observation for the study of modern societies" worldwide (Morier-Genoud and Péclard 2007: 2). Some have focused on European constructions of knowledge about Africans as mediated by missionaries desirous of producing an African voice for European audiences (Harris 2007). Some have emphasized the local encounters within transnational mission movements (Hielssen, Okkenhaug and Skeie 2011). Others have examined power-relations beyond written discourses, observing the ordered and timed routine of the mission 
station or scrutinising the constructed physical space of the mission station to ask how Christianity shapes space and is shaped by it (Skeie 2012). They unearth the complexities of social-cultural transformations in situ and in communication with 'home'. Missionary sources are vital in these works, but although all authors assert African influence and agency as local carriers of transnational religious ideas and practices, some authors are less successful at maintaining a focus on the African participation in cultural change. Furthermore, a familiar periodization is re-enforced when the starting point of these narrative is often the arrival of missionaries which means that prior healing, renewalist or resistance movements can be overlooked.

Another stream of literature critical of post-colonial readings examines the role of converts and evangelists as 'cultural brokers' (Brock 2005; Grimshaw and May 2010; Brock, Etherington, Griffiths, Van Ghent 2016; Wild-Wood 2016, 2020), rather than as agents of colonialism (Tiberondwa 1998). Missionaries depended on indigenous Christians to broker relationships across cultures and negotiate mutual exchange being between a missionary or European culture and the evangelist's own culture (Etherington 2005: 1-18). Knowledge of local society, language and customs gave African evangelists influence with European missionaries who wished to obtain knowledge and gain the trust of local people. This form of power could be operated successfully, and its execution undermined notions of perpetual victimhood for indigenous people living within a colonial state. An examination of Africans who were instrumental in the propagation of Christianity has also encouraged the production of biographies of prominent indigenous Christians, many of which utilise missionary sources as part of an archival repertoire (Ajika 2008; Brock 2011; Olabimtan 2013; Ekebuisi, 2015).

The two broad and competing interpretations of missionary religion via missionary sources that have been elucidated here are not necessarily mutually exclusive. It is quite possible that missionary activity, in general terms, can be both assault and exchange. Examining particular historical circumstances reveals the extent to which any given incidence is destructive or supportive of any particular cultural aspect. In an attempt to explore relations beyond these binaries the next section of the chapter shows how missionary sources reveal encounters between European missionaries and local clergy and teachers in which common commitments and shared ideas are prominent, and in which a vision of belonging to an international, trans-temporal community was attractive to both parties. One obscure and humorous missionary story unearthed when researching the religious encounter in western Uganda will serve to raise questions of interpretation in order to illuminate the need for careful study of missionary documents which contain information about 
African Christians and their role in bringing trans-regional ideas to sites of local cultural change.

\section{Bicycles and Wisdom: A Case Study}

Ruth Fisher (née Hurditch) arrived in Toro in 190o, one of the first two female missionaries of the Church Missionary Society (CMS) to work in the district. Fisher wrote a number of published and unpublished sources in different genres which include descriptions of local people and Ganda evangelists. She recounts in some detail an extended safari in 1901 organised and led by Apolo Kivebulaya to acquaint her and Edith Pike with the peoples of Toro. In her description is the following amusing vignette.

We steamed along on our machines, under sun-hats and big shades, over ridges and through mud. Apolo insisted on keeping pace with the ladies' bicycles, and as small batches of natives passed on the road, gazing with blank astonishment at these "running snakes," he called out with pride and elation, "Look at the wisdom of the white man!' Just as he shouted this for a third-time my bicycle tumbled clean into an ant pit and was irreparably smashed. The people did not evince any concern or surprise: they evidently considered it part of the show. One of the onlookers was chartered to shoulder the fragments back to Kabarole. Once more I was without my bicycle and I felt sure that the natives must have wondered where the wisdom came in.

'Grandmother's Tracks' 54. On the Borders of Pigmyland, p.109

The vignette can be read in a number of different ways in order to examine the role of African teachers and their relationship with missionaries. The gaze of bystanders could be interpreted as uncomprehending and bewildered or as resentful and mistrusting towards overdressed white women propelling themselves on strange constructions. Kivebulaya's adulation of missionary methods of transportation could be understood as a tool in a complex kit for indigenous survival in an oppressive missionary regime. His praise could be understood as that of a colonial collaborator displaying false consciousness, or the unconscious propagator of malevolent, exterior influence, or the social go-between copying the ways of missionaries and promoting novel technologies. Perhaps Kivebulaya's exclamation was a tongue-in-cheek comment, whose sarcasm was overlooked by a proud and ignorant European. Or maybe it was made in envy for a vehicle that Hunt sees as "colonial commodity, a 
symbolic marker of middle status" (Hunt 1999: 176). In contra-distinction to these possible readings and having studied other documents, I understand that Fisher and Kivebulaya both participate in a sense of excitement, novelty and adventure - although not always about the same things. The journey they take is an example of collaboration on a shared - but differently perceivedcommitment to a common cause. It is in those differences of perception that the less obviously documented elements of cultural exchange, the perspectives of African teachers, may be found. In this reading, an amusing, incidental event provides us with a glimpse into shared activities of a Ugandan Christian and a European missionary who understood intercultural relations and novel technologies to be tangible symbols of a global Christian community. An understanding of Fisher's writing and recourse to other sources are required in order to be confident of such an interpretation. As they are deployed below the possibilities and problems of some missionary sources are revealed.

Fisher's story is found in two sources. It was published in On the Borders of Pigmyland (1904), a travelogue composed from a much longer journal, made available by Fisher's family with biographical notes as 'Grandma's Tracks.' There are references to the journey in the published cMs Annual Letters 1901 and in Kivebulaya's diary. ${ }^{1}$ The description of events in both versions is very similar and shows how closely Fisher adhered to private notes in describing events. However, there are some additions and subtle changes which are more than merely stylistic. Reading these sources allows us to understand Fisher's context and her values and opinions. The person of Kivebulaya is partially revealed but only by knowing about the background of the Fisher. A comparison with other documents further permits a deeper reading of missionary sources.

Fisher's writing is set within late Victorian Anglican evangelicalism and in the perpetually negotiated emancipatory roles it provided for women. Her bicycle had given her freedom of movement in London. To avoid being carried by porters she took it to Uganda where she had ridden it successfully on the wide Buganda roads. Her bicycle establishes her credentials as a modern missionary woman: credentials she mocks in this vignette. She does not record Kivebulaya's awe from a position of condescension or superiority. She is as equally excited as Kivebulaya about her bicycle and ruefully she accepts the flaws in her beloved mode of transport on Toro tracks unfit even for a boneshaker.' The vignette is embedded in a description of the safari which begins with Fisher's praise of Kivebulaya. He is the experienced traveller, he is her 'protector and overseer'. She describes his bravery and good work, bestowing upon

1 The CMS archives are housed at the University of Birmingham. Kivebulaya's diary is kept in the Africana Collection at Makerere University. 
him the epithets 'noble' and 'faithful'. Faithfulness has complex meanings in this context. It can be used of an inferior, like a loyal dog or servant. However, it is also a virtue expected of committed Christians in response to God's prior faithfulness. Fisher's misplaced faith in technology reminds her that she is not so wise or able and she must look elsewhere for dependability. She relies on Kivebulaya's knowledge of local people and places, and his interpretation of their societies in order to navigate the journey beyond the Kaberole mission station. Furthermore, Kivebulaya's experience persuades the male European missionaries that the 'ladies' may undertake a potentially hazardous trip. Thus Kivebulaya acts as both chaperon and liberator, enabling the women to both subvert and conform to Victorian social expectations of their class which they were already redrawing by being missionaries. In reading missionary texts in this way the gendered relations are foregrounded and the interaction between Fisher and Kivebulaya is infused by social, and cultural forces from missionary's background.

Relationship between missionaries and indigenous peoples are often illuminated in missionary writings that articulate both lofty aspirations and stern criticism of local cultural practices. Fisher provides much greater commentary in the published book as she interprets her travels for a wider audience. In the same chapter that recounts the bicycle incident and praises Kivebulaya, Fisher describes the 'fascination' of her encounter with the peoples to whom Apolo introduces her and she takes to task European 'biased opinion,' by countering what she believes to be commonly held assumptions. She blames European mistrust for poor relations between African and Europeans.

Dispel all preconceived ideas, study the people's environment, the external and internal influences that sway them, approach them not as "niggers" but fellow creatures, and the European will never need to complain of the black man's presumption, but will find it even possible to accept the inspired statement, "God ... hath made of one blood all nations of men."

\section{On the Borders of Pigmyland: 110}

Her reference to Acts 17:26 (Authorised Version) in this context is an attack on assumptions of racial superiority and a statement of belief in a common humanity. The dependence on Kivebulaya which Fisher displays also indicates the way in which their relationship bore out Fisher's biblically-based aspirations. Similar respect is also present in Fisher's popular anthropological account, Twilight Tales of the Black Baganda (1911) in which royal customs are carefully recounted, as explained by the kings of Toro and Bunyoro. Yet 
Fisher, like other missionary writers, strains at the categories she has at her disposal to explain her experiences to British audiences and she often presents Africans in ways which are conflicted. She sensitively describes character, events and customs that she admires whilst also criticizing ways of life. For example, Fisher distains the lack of motivation for material improvement. She sees lethargy, laziness and lack of interest in the gospel in a disregard for cotton clothing or durable building material among some people she visits. These people are placed in stark contrast to the native teachers who worked for calico, and gazed wistfully at bicycles. Fisher mocks herself for being overdressed and she asserts that there is no material benefit in Christianity but, nevertheless, she understands the aspiration for cotton and other material novelties as denoting an interest in Christianity. Assumptions about cultural superiority hover through her writings whilst she attempts to hold up a vision of human equality. In passages in which Fisher appears to entirely disregard her own advice and criticises the peoples she meets, can be glimpsed a distorted view of the many who remained hostile or indifferent to missionary programmes. In Toro, the royal household and its associates accepted Christianity with some rapidity and sought to propagate it throughout the fragile kingdom. A careful reading of Fisher's writings gives us some indication of the variety of cultural responses to Christianity in the kingdom that informed what were also political decisions.

Where possible, missionary sources should be read with other sources in order to examine a number of perspectives at work and construct ways in which expectations crossed or not. Below we will compare Kivebulaya's diary account with Fisher's account, as an example. Kivebulaya kept brief notes of many of his journeys, including travels with other CMS missionaries over three decades. Diary entries confirm that Kivebulaya's role as a teacher-and later as an Anglican priest-included much itineration, that he enjoyed visiting places to preach the gospel or support new churches and that he relished the role of guide to missionaries and mediator between them and indigenous people. For example, in 1931 Kivebulaya records an itineration with Bishop Willis and Revd Russell who both wrote their own accounts available in the Church of Uganda archives in Mukono. Further comparison could be made with records of journeys of explorers, colonial administrators and other missionary groups (like the White Fathers operating in Toro) to examine patterned behaviour of journeying. Along with anthropological work, such comparison is able to place missionary itinerations in a longer history of hospitality and hostility. Chiefly guests and wealthy traders moved in style and were greeted with great ceremony (Stoner-Eby 2003: 160-162). The expectations of ritual courtesy were respected during missionary itinerations. The using of comparative sources 
permits the identification of events that in any one account might appear incidental, or be described as idiosyncratic, so that the transnational encounters are seen to be infused by African social and cultural forces.

Kivebulaya's diary entries for his itineration with Fisher and Pike in 1901 are typically terse and statistical. He lists the ten destinations they visited and notes the numbers of people that gathered to meet them during their itineration. Kivebulaya also indicates that he considered industrious manual labour to be a virtue, but in contrast to Fisher's attention to idleness, he says that he encouraged those people they met who were working hard. They were road constructors, doing the same work in which Kivebulaya had been previously employed by the ruler of Buganda. In 1913, Kivebulaya bought his own bicycle. A broken bike may well have demonstrated the foolishness of the European in 1901 but its possibilities for efficient travel were much greater when the labourers had made the Toro roads better suited for wheels. For Kivebulaya, journeying with Fisher and Pike (and other missionaries) provided the signs of what he has been preaching: his message of eternal life in Christ was bound up in the material novelties and the benefits of belonging to an international movement in which strangers became siblings. His pale, overdressed fellow-missionaries balanced on strange contraptions provided a spectacle and a talking point. They lent Kivebulaya credibility amongst those prepared to countenance his teaching. Even the embarrassment of a broken bicycle became an opportunity to draw attention to road construction. He and other evangelists relied on performative elements surrounding travel and hospitality in order to draw attention to their message. When read with other documents Kivebulaya's diary shows the agency of indigenous people and demonstrates that novelties brought by westerners need not be understood as necessarily homogenising. Novelties could be vehicles-literally in this case-by which some local actors chose to engender change on translocal levels.

This section started with an amusing vignette found in a description of missionary itineration. The examination of a single story and related sources has demonstrated in microcosm some problems and possibilities in the use and interpretation of missionary sources. Missionary sources facilitate a number of overlapping enquiries: the missionary endeavour itself, the mediating role of church teachers, glimpses into communities who were uninterested by the Christian gospel, and ways in which the transnational adoption and adaption of Christianity worked in early encounters. Further insight into missionary writing requires an understanding of the variety of the sources. With reference to some documents already mentioned above, the final part of this chapter examines the nature and genre of missionary sources. 
The analysis of possible interpretations of an amusing story has introduced some of the documents that are available to the researcher. It has also demonstrated that it is important to know what kind of source-its audience, genre and conceptual frames-is being used. Many missionary societies, including the CMs for whom Fisher worked, had a vast range of communications. This final section of the chapter analyses the range of genre and publications in which missionaries wrote in order to argue for two points: first, the importance of comprehending the nature and rationale of sources at historians' disposal for effective interpretation (even when missionary concerns are not central to the history of indigenous Christianity under investigation); second, the utility of a comparison of different sorts of missionary writing in order to gain a deeper understanding of the context. These points hinge upon two important issues: missionary writers were conscious of various audiences and they wrote according to their audiences' interests. They wrote for missionary societies requiring statistics and demonstrations of diligence, the general public and learned societies seeking different forms of knowledge about Africa, the supporters desirous of information for prayer and financial assistance, and close confidantes who expected frank accounts. The missionary sources categorised below were influenced by the perceived interests of potential readers and viewers. The way in which the sources are organised, archived and conceptualised also plays a role in our understanding of their historical significance (Stoler 2009: 32-38, 52; Burton 2005: 6-9).

The official publications of missionary societies have gained particular attention as interest in missionary sources has increased. They have been studied as a genre in their own right called 'missionary literature,' which is characterised by a propagandist intent and highly-regulated content (Johnson 2003: 6-7). This formal literature is extensive, well-known and provides valuable information. The accessibility of this literature has played a role in its use. Large missionary societies of mainline churches in Europe and the USA have often been studied because they have housed their archives in academic institutions or provided funding for their maintenance, cataloguing and, increasingly, their digitisation. ${ }^{2}$ Smaller, independent societies have not always provided the same resources for generating, maintaining or making accessible their literature and

2 Two databases of British missionary archives and periodicals are useful finding aids: Mundus Gateway to mission archives \& resources http://www.mundus.ac.uk/links.html\#uk. Missionary Periodicals Database http://divdl.library.yale.edu/missionperiodicals/Default. aspx. 
correspondence and have consequently received less attention to date. The Church Missionary Society (CMs) provides a good example of this official missionary literature. The archives housed at the University of Birmingham are a vast collection of institutional papers and correspondence with missionaries. The daily concerns of the institution do not always reflect the intercultural encounters of missionaries. CMS also produced a variety of periodicals intended to promote its aims and increase its support in Britain and targeted at different audiences and changing tastes over its two-hundred-year history. They include the Intelligencier (1846-1906) which aimed to provide detailed and informative articles, the Gleaner (1841-1921) which had a more popular approach, special interest periodicals (like the Mission Hospital 1922-1939) and periodicals for children (like Children's World 1891-1900). Missionary correspondence was reproduced for the volumes of Annual Letters and edited by staff in London for the society's annual reports, Proceedings of the Church Missionary Society. Like the publications of other mission agencies these were predominantly written by male European missionaries. Nevertheless, they include letters of female missionaries (including Fisher and Pike) and occasional reports from indigenous leaders. Outlook 57 [September 1930], includes translated letters from the King and Queen Mother of Toro and Apolo Kivebulaya). The volume of material produced and stored by large missionary societies has meant that scholars have often limited their attention to official publications of a single mission. These sources provide a huge quantity of reportage of events, characters, strategies and statistics. Nevertheless, a study which relies upon this kind of 'missionary literature' for its sole insight into missionary activity is liable to emphasise the institutional concerns of the organisation in the metropole, the interests of the missionary supporting public, and the way in which the mission field was conceived in the metropole. Missionary writing is much wider than the literature published by the headquarters of any society.

Missionaries published books of their experiences, not all of which were published by missionary presses. Missionary literature has been criticised for focussing on positive stories of foreign missionary success and ignoring indigenous agency (Johnston 2003: 7). Missionary struggles were part of a larger Christian expectation of sacrifice and suffering for the propagation of the gospel. Such narratives can form tropes of heroism, persecution and martyrdom that glorify the missionary endeavour. However, book-length treatments can reveal more complex narratives. Longer memoirs can discuss death, lack of converts, friendships and loneliness in less stylised manners that missionary periodicals. CMS publications included several biographies of Kivebulaya by $\mathrm{AB}$ Lloyd presenting Kivebulaya as a figure whom British Christians should emulate (1923, 1929, 1934). Fisher's two books include self-deprecatory 
incidents and descriptions of the daily lives and roles of indigenous co-workers and political leaders (1904; 1911). By publishing with Marshall Brothers Fisher reached a Christian audience wider than CMS supporters with her travel narrative and evangelical critique of assumptions of racial hierarchy. In contrast, $\mathrm{AB}$ Lloyd's travelogues which were published by secular publishing house, Unwin, are replete with 'Boy's Own' style adventure (Wild-Wood 2010: 285-288) and show a closer imbrication of colonial and missionary perspectives and a greater acceptance of imperial ideals that were often critiqued elsewhere within missionary circles (Griffiths 2005: 53-55).

Regional publications are sometimes overlooked. They often contain greater local detail than was considered necessary in general publications. Nancy Hunt made use of Yakusu Quarterly Notes to access the letters of Congolese Baptists. CMs's Uganda Notes has contributions from an emerging lay Christian elite as well African church leaders and European missionaries. Regional publications show that the authorial boundaries of 'missionary literature' were porous, extending to Africans who identified with the missionary enterprise. Furthermore, missionary printing presses were often used for indigenous newspapers and magazines. In Uganda, two vernacular publications emerged in the early twentieth century to address the concerns of the growing literate and Christian public. Ebifa mu Buganda (est. 1907) was supported by CMS and Munno (est.1911) by the Roman Catholic White Fathers, copies of which can be accessed in Makerere University, Kampala. The contributions within these Luganda periodicals include discussions of religious and social affairs, poems, proverbs, obituaries of Church leaders and accounts of customs and traditional ways of life. Kivebulaya, for example, contributed to Ebifa and in its pages he is eulogised after his death. These periodicals contributed to information dissemination in the wider East African region. Henry Wright Duta, an early Ganda clergyman and prominent Bible translator, wrote for Ebifa and for Msimulizi, the Swahili magazine of St Andrew's Kiungani, the Universities Mission to Central Africa school in Tanzania, where he had studied (Stoner-Eby 2003: 173). The information sharing and knowledge production by Christian elites in print-media provides historians with accounts of current events and interpretations of the past. These periodicals also illuminate three developments influenced by the spread of Christianity. First, they show the asymmetries of influence among African populations in which particular languages and their speakers gain prominence. Second, they demonstrate multidirectional transnational connections beyond a familiar north-south trajectory (Koschorke 2016: 42). Third, they demonstrate the development of a Christianised ethno-nationalism and the inculcation of panAfrican and transcontinental identities as Christian elites shared stories of 
Christian expansion and examples of greater autonomy across nations and continents (Koschorke et al. 2016: 11-20).

Missionaries contributed to the production of knowledge in a variety of academic disciplines and so there are porous borders between what might be called missionary writing and anthropology, geography, medicine and so on (Harries and Maxwell 2012: 1-29). Ruth Fisher wrote the first anthropological work on the Nyoro, which was admired by later anthropologists despite its popular style because of her interviews with local authorities on traditional ways of life (Fisher 1911). The second anthropological work on the Nyoro, The Bakitara (1923), was also written by a missionary, the Revd John Roscoe, better known for his classic work, The Buganda (1911), in which he collaborated with another amateur historian and anthropologist, Apolo Kagwa, the Prime Minister of Uganda. Fisher's husband, A.B. Fisher, became a member of the Royal Geographic Society after submitting a lengthy report on the Rwenzori Mountain Range. Missionaries provided descriptions of indigenous societies as they encountered them, and as they learnt about them through relations with local people. The African involvement in these collaborations deserves further study. Careful reading of these missionary investigations of the preChristian past can indicate the shifting concerns of healing cults and the influence of African rulers on rituals of prosperity. Missionary commentary on these societies was infused with Christian assumptions, but even these assumptions do not conform to one understanding - some saw continuity between Christianity and African beliefs and practices, others saw profound differences.

A final source of missionary writings is private papers. Missionaries were often encouraged to keep journals in preparation for official accounts to be written for headquarters. They wrote private and round-robin letters to friends, family, home-churches and corresponded with other missionaries and African colleagues. These letters often contain more local detail and describe events incidental to that required by mission agencies. They have a warm, even intimate, quality and are frequently frank in their accounts and opinions. The comparison between private letters, diaries and published records of the same events can be illuminating, as a study of Fisher's bicycle story demonstrates. Private papers may be the most difficult to access because they are not always held with the institutional archive. The Cambridge Centre for Christianity Worldwide, for example, has an archive of private missionary papers donated by family members. The largest holding in its possession is 33 boxes of the Joe Church archive. From the 1920s, Church, a Ruanda Mission (CMs) doctor, kept a rich and varied collection of correspondence, diaries, press cuttings, minutes, reports, audiotapes, photographs, annotated books and pamphlets. The collection provides insights into the history of the East African Revival and its 
international impact, and prominent African and European figures, women in the movement, relations with colonial officials (Barringer 2012). The Joe Church collection offers just one example of the way in which private papers add to the variety of missionary sources.

Missionary sources are not limited to published and manuscript writings. They include the visual and the material. Photographs are found in considerable quantities in many mission archives. ${ }^{3}$ The art of skilled missionary photographers demonstrates how photography allowed missionaries greater liberty than did their official written reports to examine indigenous cultures (Jenkins 2001: 73) and it reveals the complexity and ambiguity of the intercultural encounter (Maxwell 2011: 73-74). For example, photographs taken by missionaries in Toro in the first forty years of the twentieth century depict the natural environment, and also show social change through the construction of churches and schools, the gathering of Christians for worship, schooling and training and individual Europeans and Africans. Some photographers, including Fisher, capture members of the royal family in traditional regalia or participating in rituals. Kasagama's willingness to pose and the warmth and respect that is apparent in the photographs demonstrate the mutual trust between Fisher and the household of King Kasagama. They also indicate Fisher's commitment to the Toro monarchy and her desire to preserve tradition and custom, whilst confining its place to occasional pageantry distinct from daily Christian occupations. Most of the Kasagama's court were members of the Anglican Church and were constantly recalibrating the extent to which they understood Christianity as a novelty or as a reconstruction of traditional values and customs. John Roscoe also took photographs and he collected objects from rituals and daily life as part of his anthropological enquiry, gifting his collection to the University of Cambridge museum of Archaeology and Anthropology. Apolo Kagwa also gave Ganda royal and traditional objects to the museum in Cambridge during a visit to England in 1903, presenting himself as a partner in the anthropological endeavour (Hand 2015: 75-76). The artefacts that missionaries collected from around the globe and their use in displays and museums have been studied as examples of networks of global exchange (Sivasundaram 2005: 179), as a source of metropolitan knowledge and as providing information on pre-Christian religious practice (Wingfield 2016).

3 Images from Protestant and Catholic missionary societies of Britain, Norway, Germany and the USA can be found at http://digitallibrary.usc.edu/cdm/topics/collection/p15799colli23. 
In providing a list of missionary sources a number of problems have been exposed. First, the sheer volume of the missionary sources means that researchers may only examine one set of archives. They may also neglect the careful work of scrutinising a variety of texts and triangulating them with other sources in order to perceive the indigenous encounter. Second, many missionary sources are written with metropolitan audiences in mind: understanding those audiences and their perspectives permits researchers to interpret more effectively what missionaries say about the indigenous people amongst whom they work. A third difficulty should be added: access to sources can present a significant problem for researchers. Some archives are better maintained or more easily accessible than others. Archives are dispersed across the globe and, as indicated above, it should not be assumed that all documentation pertaining to missions is found in the western world. Nevertheless, the majority of missionary literature is held in the country of origin of the missionary societies. It is usually best understood, however, in conjunction with sources from the country of missionary encounter.

This chapter has also revealed the possibilities of missionary archives. Historians of World Christianity who wish to give priority to indigenous sources in an attempt to provide a polyvocal perspective on historical events will find in missionary sources a rich seam of historical material. They encompass a great deal of material beyond that which was produced by the headquarters of missionary societies, and cannot be understood as a single genre with a master narrative. They include scientific writing, photographs and artefacts. They also include publications to which indigenous Christian elites contributed who were- to one extent or other-engaged in the missionary project. A careful reading of these publications begins to collapse grand post-colonial narratives and to show that, even in situations where the asymmetries of political power loomed large, there was between foreign missionaries and indigenous people trust and friendship. Nevertheless, in order to achieve a polyvocal perspective, missionary sources require triangulation with other sources - oral history data, the work of local historians, student dissertations, the private records and letters of early Christians. The diaries, letters and short autobiography of Apolo Kivebualaya have provided just one example of the perspectives of one who embraced religious change and who recorded his work of preaching and church planting. If they are judged on the intent of the author, then Kivebulaya's writings are every bit as much missionary sources as the records of European societies and their agents. His record illustrates the extent to which indigenous and foreign missionaries collaborated in a shared endeavour. 
This chapter has examined recent studies of religious encounter in subSaharan Africa in order to demonstrate the use of missionary sources. Their problems and possibilities were explicated through a sustained example and an examination of the variety of sources available. The reading of missionary sources presented here rejects the view that missionaries' record of events was always laughably at odds with the African perception of missionary endeavours and that missionary documents at best hold a distorting mirror to change which they could not perceive clearly (Hunt 1999: 3-4). Missionaries had a conflicted and changeable relationship with colonialism influenced by status in their home societies, the church and mission agency to which they belonged and their theological and cultural perspectives (Porter 2004:13). Thus the missionary record may elucidate changes in the metropole when it appears to represent indigenous voices. Nevertheless, information on indigenous populations can be gleaned from missionary sources. Missionaries wished to instigate change - individual, spiritual change through conversion, medical and educational change. They also wished to protect societies from too much change or the wrong kind of change, and so were interested in the cultures in which they worked. Careful analysis is necessary in order to provide a layered comprehension of events. The evidence contained in missionary sources can be triangulated with other sources in order to gain indigenous perspectives. They reveal that some indigenous views were regional, national and transnational and that some indigenous people were drawn to be part of a global community.

Comprehension of missionary sources is essential if the transregional and pluriform nature of Christianity is to be explored: indeed, it is here that the strength of a fresh approach to missionary archives lies. If a World Christianity approach has attended to the polycentricism of Christianity, then the use of missionary sources is a reminder of the global and translocal connectivities that informed particular Christian expressions. They provide one way of tracking commonalities in different parts of the globe by showing larger-scale connections, networks, and cultural exchange. Missionary sources can indicate the local appeal of a vision of human cosmopolitanism and Christian universality.

\section{Bibliography}

Ajika, M. Sjalbonyo (2008). Daudi Lyenga. Premier Catéchiste de l'Ituri. Evêché, Mahagi-Nioka.

Barringer, Terry (2012). '“Recordings of the Work of the Holy Spirit”' In Kevin Ward and Emma Wild-Wood, eds. The East African Revival. History and Legacies. Surrey, Ashgate: 177-186. 
Bayly, Christopher (2004). The Birth of the Modern World, 1780-1914. Global Connections and Comparisons. Oxford: Blackwells.

Brock, Peggy, ed. (2005). Indigenous Peoples and Religious Change. Leiden and Boston: Brill.

Peggy Brock (2011). The Many Voyages of Arthur Wellington Clah. A Tsimshian Man on the Pacific Northwest Coast. Uвс Press: Vancouver.

Brock, Peggy, Norman Etherington, Gareth Griffiths, Jacqueline Van Ghent (2016). Indigenous Evangelists and Questions of Authority in the British Empire, 1750-1940. First Fruits. Leiden: Brill.

Burton, Antoinette (2005). 'Introduction. Archive Fever, Archive Stories.' In Antoinette Burton, ed. Archive Stories. Facts, Fictions, and the Writing of History. Durham, N.C.: Duke University Press: 1-24.

Comaroff, Jean and John Comaroff (1991). Of Revelation and Revolution, Vol. 1. Chicago: Chicago University Press.

Cooper, Frederick and Laura Anne Stoler (1997). 'Between Metropole and Colony. Rethinking a Research Agenda.' In Frederick Cooper and Laura Anne Stoler, eds. Tension of Empire. Colonial Cultures in a Bourgeois World. Berkeley: University of California Press: $1-56$.

Ekebuisi, Chinonyerem C. (2015). The Life and Ministry of Prophet Garrick Sokari Braide. Elijah the Second of Niger Delta, Nigeria (c.1882-1918). Bern: Peter Lang.

Etherington, Norman (2005). 'Introduction.' In Norman Etherington, ed. Missions and Empire. Oxford: Oxford University Press: 1-18.

Fisher, Ruth R (1904). On the Borders of Pigmyland. London: Marshall Brothers.

Fisher, Ruth R (1970 [1911]). Twilight Tales of the Black Baganda. London: Frank Cas.

Fisher, Margaret, ed. (2010). Grandmother's Tracks. Private publication.

Griffiths, Gareth (2005). 'Popular Imperial adventure fiction and the Discourse of Missionary Texts,' In Jamie S. Scott and Gareth Griffiths, eds, Mixed Messages. Materiality, Textuality, Missions. New York: Palgrave MacMillan.

Grimshaw, Patricia and Andrew May (2010). Missionaries, Indigenous Peoples and Cultural Exchange. Brighton: Sussex Academic Press.

Hand, Rachel (2015). 'Brass Necklet, Uganda.' In Karen Jacobs and Chantal Knowles, Chris Wingfield, eds. Trophies, Relics and Curios? Missionary Heritage from Africa and the Pacific. Leiden: Sidestone Press: $75^{-76 .}$

Harries, Patrick (2007). Butterflies and Barbarians. Swiss Missionaries and Systems of Knowledge in South-East Africa. Oxford: James Currey.

Harries, Patrick and David Maxwell, eds (2012). The Spiritual in the Secular. Missionaries and Knowledge about Africa, Grand Rapids, MI: Eerdmans.

Hilde, Hielssen, Inger Marie Okkenhaug, Karin Hestad Skeie, eds (2011). Protestant Missions and Local Encounters in the Nineteenth and Twentieth Centuries. Unto the Ends of the World, Leiden: Brill.

Hovland, Ingie (2013). Mission Station Christianity. Norwegian Missionaries in Colonial Natal and Zululand, Southern Africa, 1850-189o. Leiden: Brill. 
Hunt, Nancy Rose (1999). A Colonial Lexicon of Birth Ritual, Medicalization, and Mobility in the Congo. Durham, NC: Duke University Press.

Jenkins, Paul (2001). 'On Using Historical Missionary Photographs in Modern Discussion.' Le Fait Missionnaire 10,1: 71-89.

Johnston, Anna (2003). Missionary Writing and Empire, 1800-1860. Cambridge: Cambridge University Press.

Olabimtan, Kehinde (2013). Samuel Johnson of Yorubaland, 1846-1901. Identity, Change and the Making of the Mission Agent. Oxford, Frankfurt am Main: Peter Lang.

Kollman, Paul (2010). 'Classifying African Christianities. Past, Present and Future.' Journal of Religion in Africa 40,1: 3-32.

Koschorke, Klaus (2016). 'Transcontinental Links, Enlarged Maps and Polycentric Structures in the History of World Christianity.' The Journal of World Christianity 6,1: $42-59$.

Koschorke, Klaus, Adrian Hermann, E Phuti Mogase, Ciprian Burlacioiu, eds. (2016). Discourses of Indigenous Christian Elites in Colonial Societies in Asia and Africa around 1900. A Documentary Sourcebook from Selected Journals. Wiesbaden: Harrassowitz Verlag.

Lloyd, Albert B. ([1923] 1934). Apolo of the Pygmy Forest. London: Church Missionary Society.

Lloyd, Albert B. (1929). More About Apolo. London: Church Missionary Society.

Lloyd, Albert B. (1934). Apolo the Pathfinder. Who Follows? London: Church Missionary Society.

Maxwell, David (2011). 'Photography and the Religious Encounter. Ambiguity and Aesthetics in Missionary Representations of the Luba of South East Belgian Congo.' Comparative Studies in Society and History 53,1: 38-74.

Manktelow, Emily (2013). Missionary Families. Race, Gender and Generation on the Spiritual Frontier. Manchester: Manchester University Press.

Meyer, Birgit (1999). Translating the Devil. Religion and Modernity Among the Ewe in Ghana. Edinburgh: Edinburgh University Press.

Morier-Genoud, Eric and Didier Péclard (2007). 'SSM. A Twelve-Year-Old "New Journal"' Social Sciences and Missions 20: 1-3.

Mudimbe, Valentin-Yves (1988). The Invention of Africa. Gnosis, Philosophy, and the Order of Knowledge. Bloomington: Indiana University Press.

Peel, J.D.Y. (1995). “For Who Hath Despised the Day of Small Things?" Missionary Narratives and Historical Anthropology.' Comparative Studies in Society and History 37,3: 581-6o7.

Peel, John D.Y. (1996). 'Problems and Opportunities in an Anthropologist's Use of a Missionary Archive.' In R. Bickers and R. Seton, eds, Missionary Encounters. Sources and Issues. Richmond, Surrey: Curzon Press: 70-94. 
Peel, John D.Y. (200o). Religious Encounter and the Making of the Yoruba. Bloomington: Indiana University Press.

Peterson, Derek R. (2011). 'Conversion and the Alignments of Colonial Culture.' Social Sciences and Missions 24,2-3: 207-232.

Peterson, Derek R. (2012). Ethnic Patriotism and the East African Revival. A History of Dissent, c.1935-1972. Cambridge: Cambridge University Press.

Porter, Andrew (2004). Religion verses Empire? British Protestant Missionaries and Overseas Expansion, 1700-1914. Manchester: Manchester University Press.

Roscoe, John (1911[1965]). The Baganda. An Account of their Native Customs and Beliefs. London: Frank Cas.

Roscoe, John (1923). The Bakitara or Banyoro. The First Part of the Report of the Mackie Ethnological Expedition to Central Africa. Cambridge: Cambridge University Press.

Sivasundaram, Sujit (2005). Nature and the Godly Empire. Science and the Evangelical Mission in the Pacific, 1795-1850. Cambridge: Cambridge University Press.

Skeie, Karin Hestad (2012). Building God's Kingdom. Norwegian Missionaries in Highland Madagascar, 1866-1903. Leiden: Brill.

Stoler, Ann L. (2009). Along the Archival Grain. Epistemic Anxieties and Colonial Common Sense. Princeton: Princeton University Press.

Stoner-Eby, Anne-Marie (2003). 'African Leaders Engage Mission Christianity. Anglicans in Tanzania 1876-1936.' Unpublished PhD, University of Pennsylvania.

Tiberondwa, Ado K. (1998 2nd ed). Missionary Teachers as Agents of Colonialism in Uganda. Kampala: Fountain.

Wild-Wood, Emma (2010). 'The Making of an African Missionary Hero in the English Biographies of Apolo Kivebulaya (1923-1936), Journal of Religion in Africa 40,3: 273-306.

Wild-Wood, Emma (2016). 'The Travels and Translations of Three African Anglican Missionaries, 189o-1930.' Journal of Ecclesiastical History 67.4: 781-798.

Wild-Wood, Emma (2020). The Mission of Apolo Kivebulaya. Religious Encounter and Social Change in the Great Lakes (c.1865-1935). Woodbridge: James Currey.

Wingfield, Chris (2016). "'Scarcely More Than a Christian Trophy Case"? The Global Collections of the London Missionary Society Museum (1814-1910).' Journal of the History of Collections 29,1: 109-128.

\section{On-line Data Bases}

Missionary Periodicals Database http://divdl.library.yale.edu/missionperiodicals/.

Mundus Gateway to mission archives \& resources http://www.mundus.ac.uk/links .html\#uk.

University of Southern California International Mission Photography Archive: http:// digitallibrary.usc.edu/cdm/topics/collection/p15799coll123; http://crcc.usc.edu/ initiatives/impa/. 


\section{Archives Mentioned in the Article}

Cambridge Centre for Christianity Worldwide

Church Missionary Archives, University of Birmingham

Church of Uganda Archives, Uganda Christian University

Africana Collection, Makerere University

Missionaries of Africa (White Fathers) Archives, Rome and http://www.mafrome -archivio.org/misafrarchives_fr.html\# 